Article

\title{
Thermal Comfort Level Assessment in Urban Area of Petrolina-PE County, Brazil
}

\author{
Pedro Vieira de Azevedo ${ }^{1}$, Péricles Tadeu da Costa Bezerra ${ }^{2}$, \\ Mario de Miranda Vilas Boas Ramos Leitão ${ }^{3}$, Carlos Antonio Costa dos Santos ${ }^{1,4}$ \\ ${ }^{1}$ Programa de Pós-Graduação em Recursos Naturais, Universidade Federal de Campina \\ Grande, Campina Grande, PB, Brazil. \\ ${ }^{2}$ Ministério do Planejamento, Orçamento e Gestão, Brasília, DF, Brazil. \\ ${ }^{3}$ Colegiado Acadêmico de Engenharia Agrícola, \\ Universidade Federal do Vale do São Francisco, Juazeiro, BA, Brazil. \\ ${ }^{4}$ Unidade Acadêmica de Ciências Atmosféricas, Universidade Federal de Campina Grande, \\ Campina Grande, PB, Brazil.
}

Received: July 21, 2016 - Accepted: January 4, 2017

\begin{abstract}
This study evaluated the thermal conditions of urban areas in Petrolina-PE, from continuous data collected in urban and rural areas for the year of 2012. The results characterized urban heat islands (UHI) with varying intensity in urban areas, especially UHI $=5.3{ }^{\circ} \mathrm{C}$ (high intensity) occurred on April 28, 2012. It was evident that the constituent elements of urban areas contribute to the formation and expansion of UHI bringing thermal discomfort for its inhabitants. An adaptation to Thom's equation for calculating the Thermal Discomfort Index $(D I T)$, was used to obtain the maximum $\left(D I T_{x}\right)$ and minimum $\left(D I T_{m}\right)$ thermal discomfort. In the urban area, the $D I T_{m}$ indicated thermal comfort in $23.0 \%$ of the days and partial comfort in $77.0 \%$ of days surveyed. Already, the $D I T_{x}$ characterized $71.6 \%$ of days with partial comfort and $28.4 \%$ of days with thermal discomfort. In the rural area, The $D I T_{m}$ indicated that $41.5 \%$ of days were thermally comfortable and $58.5 \%$ of days had partial comfort. However, the $D I T_{x}$ pointed $87.7 \%$ of the days of this environment with partial thermal comfort and $12.3 \%$ of thermally uncomfortable days. Finally, the results showed that afforestation of urban area constitutes to an effective and efficient way to mitigate thermal discomfort.
\end{abstract}

Keywords: urban and rural areas, air temperature and humidity, heat island.

\section{Avaliação do Nível de Conforto Térmico na Área Urbana do Município de Petrolina-PE, Brasil}

\begin{abstract}
Resumo
Este estudo avaliou as condições térmicas da área urbana de Petrolina-PE, a partir de dados contínuos coletados nas áreas urbana e rural durante um ano de 2012. Os resultados caracterizaram ilhas de calor (IC) com intensidade variada na área urbana, com destaque para $\mathrm{IC}=5,3{ }^{\circ} \mathrm{C}$ (forte intensidade) em 28/04/2012. Ficou evidenciado que os elementos constitutivos das áreas urbanas contribuem para a formação e expansão de IC que geram desconforto térmico para a população e, a partir de uma adaptação à equação de Thom para cálculo do índice de desconforto térmico (IDT), obteve-se os índices de desconforto máximo $\left(I D T_{x}\right)$ e mínimo $\left(I D T_{m}\right)$. Na área urbana, o $I D T_{m}$ indicou conforto térmico em $23,0 \%$ dos dias e conforto parcial em $77,0 \%$ dos dias pesquisados. Já o $I D T_{x}$, caracterizou $71,6 \%$ dos dias com conforto parcial e $28,4 \%$ dos dias com desconforto térmico. Na área rural, o $I D T_{m}$ indicou que $41,5 \%$ dos dias foram confortáveis termicamente e $58,5 \%$ dos dias tiveram conforto parcial. Contudo, o $I D T_{x}$ nesse ambiente apontou 87,7\% dos dias com conforto parcial e $12,3 \%$ dos dias termicamente desconfortáveis. Por fim, os resultados obtidos demonstraram que a arborização da área urbana da cidade constitui-se numa forma eficaz e eficiente para mitigar o desconforto térmico.
\end{abstract}

Palavras-chave: áreas urbana e rural, temperatura e umidade do ar, ilha de calor.

Autor de correspondência: Carlos Antonio Costa dos Santos, carlos.santos@ufcg.edu.br. 


\section{Introduction}

Many cities have been seen as icons of the environmental crisis, problems related to urban space are the most diverse and among the possible issues are most prominent climate change. The perception that the city is a modifier of climate and human activities that cause changes in the atmosphere triggered climate studies that forms in the cities, called urban climate, which constitutes one of the most relevant factors for the environmental quality of built environment (Andrade, 2005; Coltri et al., 2007). The weather is the element that interacts with all environmental systems and their study promotes multidisciplinary analyzes with planners: engineers, architects, meteorologists, historians and geographers, among others, in seeking solutions to environmental problems in cities with consequent improvement of life of the urban population. The human activities cause changes in the atmosphere triggered climate studies of the cities, called urban climate, which constitutes one of the most relevant factors for the environmental quality of the built environment (Coltri et al., 2007). The cities intense urbanization causes interurban climatic conditions that are directly related to the heterogeneity of land use and urban features, generating heat islands and wet and dry islands (Sousa Júnior, 2006; Viana and Amorim, 2008; Silva et al., 2009). According to Johansson (2006), in hot and dry climates, a compact urban model is preferable. However, if there is a cold season this urban model must include some wider or open spaces or both streets to provide access to solar radiation. In the search for alternatives to offer thermal comfort in environments already built, Alexandria and Jonesb (2008) found that a reduction of temperature, improved thermal comfort, and energy savings with the roofing and walls with some vegetation. Thus, thermal comfort can be approached based on human and environmental variables (Armelin and Krüger, 2002; Nicol and Humphreys, 2002; Barbosa et al., 2003; Corbella and Yannas, 2003; Farm and Labaki, 2003; Kwok and Chun, 2003; Prado and Ferreira, 2005; and Lamberts et al., 2011).

In Brazil, the semiarid region is one of the most vulnerable geographic area to the effects of climate change, characterized by high average annual temperature $\left(27^{\circ} \mathrm{C}\right)$ and subsequent high evaporation rate $(2,000 \mathrm{~mm} / \mathrm{yr})$. A maximum annual rainfall of $800 \mathrm{~mm}$ is unevenly distributed in time and space, causing serious social consequences for its more than twenty million inhabitants. In general, soils are shallow, with occasional rocky outcrops, stony ground, and vegetation type Caatinga covering almost all the environment. The combination of these elements contributes to a negative water balance for most of the years, the presence of dry rivers and intermittent episodes of cyclical droughts.

Due to the proximity of the Brazilian semiarid region with the equator, there is naturally high incidence of solar radiation in the region. Thus, cities have higher temperatures than other more south of the country. In this process, one of the mechanisms of the system-town atmosphere most affected by the land use and cover change is the energy balance, as evidenced by the generation of heat islands (Perez et al., 2001; Azevedo and Price, 2001; Araújo and Sant'Anna Neto, 2002; Kalnay and Lime, 2003; Monteiro and Mendonça, 2003; Silva et al., 2009). Studies of energy balance in urban areas have shown that, contrary to what occurs in natural areas, the sensible heat fluxes have become much higher than the latent heat fluxes, causing an increase in the urban temperature as compared to the rural environment (Oke et al., 1992). On the other hand, the progress of some Brazilian semiarid cities helps explaining changes in their urban structures, especially regarding the lining of their public roads. So that, the central areas of cities experience a rise in temperature, a phenomenon known as urban heat island (UHI), a thermal anomaly which occurs when the air becomes warmer than the air in the surrounding areas (Oke, 1991; Alucci and Monteiro, 2005). The paving of the streets and concentration of concrete structures mainly cause such occurrences because the asphalt has great ability to store heat buildings and alter the arrangement of the winds.

The temperature difference between the city and its surroundings causes environmental differences between urban (higher temperatures) and rural (lower temperatures) areas. These differences form updrafts over the warmer parts of the city, which move the urban periphery to the most heated areas, conducting air pollutants generated in the periphery to the urban center. These pollutants will join those already on the urban center, intensifying the problem of environmental degradation in cities. That is, the already adverse natural conditions of the semiarid region are enhanced by the building blocks of urban structures that contribute more markedly to worsen the quality of life in urban centers with increased thermal discomfort to the population (Bezerra, 2009).

Unsuitable weather conditions in urban environments means loss of life quality for some and increase of electricity for thermal conditioning of built environments for others. As a result, there is an increase in demand for electricity, due to the need for expansion of power generation matrix: hydroelectric, thermoelectric and nuclear power plants, among other ways of producing energy, all with great impact on the environment (Lamberts and Xavier, 2002).

In this context, knowledge of urban climate is a key to the development of cities parameters because it provides information for better planning and management of its physical space. Therefore, it becomes urgent to include this environmental vision in the technical, economic and political scenarios that shape the urban environment, considering the natural and anthropogenic processes that occur in cities in the ongoing quest for sustainable development (Pine, 2008). Thus, climate and urban planning studies should be considered as input to development of assessments of the 
physical space of cities, with the hypothesis that climate influences the environment and vice versa. Given the above, this study aimed to evaluate the occurrence of heat islands and the level of thermal discomfort in the urban area of the municipality of Petrolina-PE.

\section{Material and Methods}

\subsection{Study area}

The experiment was conducted in urban and rural areas of the municipality of Petrolina-PE (Area: $4,756.8 \mathrm{~km}^{2}$ and Population: 294.081 inhabitants), inserted in the Brazilian semiarid region (Fig. 1). This municipality has the following climate characteristics: very dry and semiarid climate with rainy season from November to April and average annual rainfall of $431.8 \mathrm{~mm}$.

\subsection{Instrumentation}

The data of temperature and relative humidity, wind speed and direction in urban and rural areas of the municipality of Petrolina-PE were collected from January $1^{\text {st }}$ to December 31, 2012. The urban area data were obtained from the meteorological station of National Institute of Meteorology (INMET), located in the neighborhood Gercino Rabbit, while data from the rural area were obtained from the Meteorological Station of the Federal University of the San Francisco River Valley (UNIVASF), located at Road BR 407, km 12 - Nilo Coelho Irrigation Project - C1. The urban area data were compared to those from rural areas, with the following analysis tools: (i) urbanization in relation to morphology/urban function; (ii) rural ecology characteristics considering the topography and most influential factor in the spatial behavior of the temperature; and (iii) the meteorological system (regional climate).

The comparative analysis of the data revealed, in addition to observation of the occurrence of UHI, the classification of its intensity, in accordance with the established by Gomez et al. (2001), stated in Table 1.

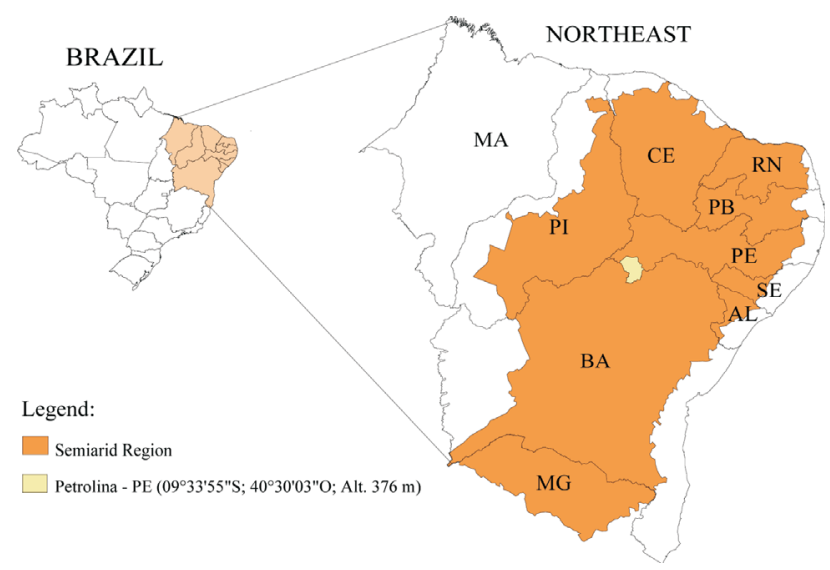

Figure 1 - Map of the semiarid region of northeastern Brazil, particularly the municipality of Petrolina-PE.
Table 1 - Intensity of heat island due to changes in air temperature.

\begin{tabular}{lc}
\hline Temperature range $\Delta T\left({ }^{\circ} \mathrm{C}\right)$ & Heat island intensity \\
\hline $0 \leq \Delta T \leq 2$ & Weak \\
$2 \leq \Delta T \leq 4$ & Moderate \\
$4 \leq \Delta T \leq 6$ & Strong \\
$\Delta T>6$ & Very strong \\
\hline
\end{tabular}

Thermal comfort was evaluated by adapting the calculation of the thermal discomfort index of Thom (DIT), as follows (Alucci and Monteiro, 2005):

$$
D I T=T-(0.55-0.0055 R H)(T-14.5)
$$

where $T$ is the air temperature $\left({ }^{\circ} \mathrm{C}\right)$ and $R H$ the air relative humidity (\%).

The studied areas showed an inverse relationship between air temperature and relative humidity, that is, the maximum air temperature occurs at times very close to the minimum relative humidity. Similarly, the minimum air temperature occurs at times close to those of maximum relative humidity. Thus, it was possible to split the calculation of DIT into two components:

$$
\begin{aligned}
& D I T_{x}=T_{x}-\left(0.55-0.0055 R H_{m}\right)\left(T_{x}-14.5\right) \\
& D I T_{m}=T_{m}-\left(0.55-0.0055 R H_{x}\right)\left(T_{m}-14.5\right)
\end{aligned}
$$

where $D I T_{x}$ is the maximum rate of thermal discomfort $\left({ }^{\circ} \mathrm{C}\right), D I T_{m}$ the minimum ratio of thermal discomfort $\left({ }^{\circ} \mathrm{C}\right)$, $T_{x}$ the maximum air temperature $\left({ }^{\circ} \mathrm{C}\right), T_{m}$ the minimum air temperature $\left({ }^{\circ} \mathrm{C}\right), R H_{x}$ the maximum relative humidity $(\%)$, $R H_{m}$ the minimum relative humidity (\%).

The information in Table 2 were used to classify the level of thermal discomfort (Silva et al., 2009):

To enable an effective comparison of the data recorded, the field experiments (clock hour) times were converted to true solar time, considering the corrections of time equation $\left(t_{e}\right)$ and the differences of longitude $(\lambda)$ :

$$
t_{a}=t_{c}+\Delta \lambda+t_{e}
$$

where $t_{a}$ is the apparent time (true solar time); $t_{c}$ the civil time (clock time); $\Delta \lambda$ the correction due to different longitudes:

$$
\Delta \lambda=4\left(\lambda_{s}-\lambda_{l}\right)
$$

Table 2 - Classes of thermal discomfort depending on the Thom thermal discomfort index $(D I T)$.

\begin{tabular}{lcc}
\hline Level & $D I T$ range $\left({ }^{\circ} \mathrm{C}\right)$ & Class of thermal discomfort \\
\hline 1 & $D I T \leq 14.9$ & Uncomfortable \\
2 & $15.0 \leq D I T \leq 19.9$ & Comfortable \\
3 & $20.0 \leq D I T \leq 26.4$ & Partial comfort \\
4 & $D I T \geq 26.5$ & Uncomfortable \\
\hline
\end{tabular}




$$
\begin{aligned}
& E_{t}=7,5 \times 10^{-5}+1,87 \times 10^{-3} \cos (\Gamma) \\
& -3,21 \times 10^{-3} \operatorname{sen}(\Gamma)-1,46 \times 10^{-2} \cos (2 \Gamma) \\
& -0,04 \times 10^{-2} \operatorname{sen}(2 \Gamma)
\end{aligned}
$$

where $\lambda_{\mathrm{s}}$ is the longitude of the standard meridian; $\lambda_{1}$ the local longitude; and

$$
\Gamma=\left(\frac{360}{365}\right)(d-1), d=\text { Julian day }
$$

\section{Results and Discussion}

On average, the urban environment of Petrolina-PE presented in the year of 2012, a maximum air temperature $\left(0.6^{\circ} \mathrm{C}\right)$, minimum $\left(1.4^{\circ} \mathrm{C}\right)$ and mean annual temperature $\left(1.1^{\circ} \mathrm{C}\right)$ higher than the corresponding values of the rural area (Table 3). According to data in Table 4, it appears that during the year 2012, on average, the maximum relative humidity of air was higher $(76.7 \%)$, while the minimum was lower $(27.8 \%)$ in rural area of Petrolina. One fact that stands out in the climate and impressive aspect of the population was the extremely low rate of relative humidity recorded at September 13, $2012(11.8 \%)$ in rural areas and $12 \%$ in urban areas. In 2012 , the wind speed showed a daily average of $3.7 \mathrm{~m} . \mathrm{s}^{-1}$ in the urban area of Petrolina, with gusts of up to $16.6 \mathrm{~m} . \mathrm{s}^{-1}$ while in the rural area it was $3.9 \mathrm{~m} . \mathrm{s}^{-1}$, with gusts of up to $19.7 \mathrm{~m} . \mathrm{s}^{-1}$ (Table 5). It was also observed that, on average, the maximum wind speed was higher in rural area $\left(14.1 \mathrm{~m} \cdot \mathrm{s}^{-1}\right)$.

Spatial attention should be given to extreme values (Tables 3, 4 and 5) since the annual weighted averages represent a large group of data and generally do not show significant differences. For better evaluating the behavior of climate variables it is presented in sequence, illustrative graphs of rainfall, temperature and relative humidity (mini-
Table 5 - Wind speed: maximum (average and absolute values with the occurrence of hours) and overall average in the period from January $1^{\text {st }}$ to December 31, 2012 in Petrolina-PE.

\begin{tabular}{lcccc}
\hline \multirow{2}{*}{ Location } & \multicolumn{3}{c}{ Wind speed $\left({\left.\mathrm{m} . \mathrm{s}^{-1}\right)}^{\text {General }}\right.$} \\
\cline { 2 - 4 } & \multicolumn{3}{c}{ Maximum } & \\
\cline { 2 - 4 } & Average \\
\hline Petrolina (rural area) & 14.1 & Absolute & Time \\
Petrolina (urban area) & 11.7 & 19.7 & $20: 00$ & 3.9 \\
\hline
\end{tabular}

mum, average and maximum) observed in urban and rural areas of Petrolina-PE.

Figure 2 shows the behavior of rainfall in Petrolina-PE, especially the irregularity and poor rainfall distribution in 2012, with the accumulated rainfall in the rural area $(182 \mathrm{~mm})$ greater to that of the urban area $(135.2 \mathrm{~mm})$. It was also noted that 2012 was an extremely dry year and

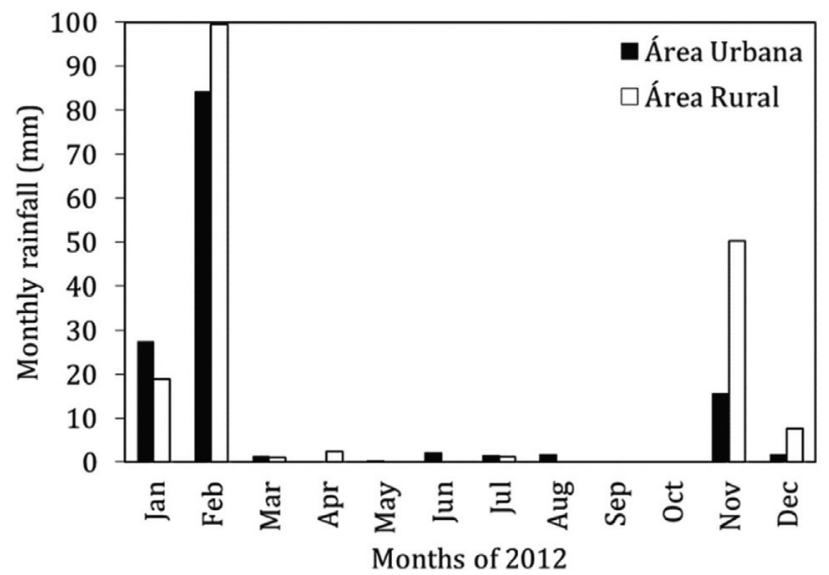

Figure 2 - Rainfall in rural and urban areas in the period from January $1^{\text {st }}$

\begin{tabular}{|c|c|c|c|c|c|c|c|}
\hline \multirow[t]{3}{*}{ Location } & \multicolumn{6}{|c|}{ Air temperature $\left({ }^{\circ} \mathrm{C}\right)$} & \multirow[t]{3}{*}{ General average } \\
\hline & \multicolumn{3}{|c|}{ Minimum } & \multicolumn{3}{|c|}{ Maximum } & \\
\hline & Average & Absolute & Time & Average & Absolute & Time & \\
\hline Petrolina (rural area) & 20.9 & 14.7 & $06: 00$ & 32.8 & 37.4 & $15: 00$ & 26.6 \\
\hline Petrolina (urban area) & 22.3 & 17.7 & $05: 00$ & 33.4 & 38.0 & $15: 00$ & 27.7 \\
\hline
\end{tabular}
to December 31, 2012 in Petrolina-PE.

Table 3 - Air temperature: minimum and maximum (average and absolute values with time of occurrence) and overall average in the period from January $1^{\text {st }}$ to December 31, 2012 in Petrolina-PE.

\begin{tabular}{|c|c|c|c|c|c|c|c|}
\hline \multirow[t]{3}{*}{ Location } & \multicolumn{6}{|c|}{ Relative air humidity (\%) } & \multirow[t]{3}{*}{ General average } \\
\hline & \multicolumn{3}{|c|}{ Minimum } & \multicolumn{3}{|c|}{ Maximum } & \\
\hline & Average & Absolute & Time & Average & Average & Time & \\
\hline Petrolina (rural area) & 27.8 & 11.8 & $14: 00$ & 76.7 & 94.0 & 05:00 & 51.0 \\
\hline Petrolina (urban area) & 28.1 & 12.0 & 13:00 & 71.3 & 90.0 & 06:00 & 48.3 \\
\hline
\end{tabular}

Table 4 - Relative air humidity: minimum and maximum (average and absolute values with time of occurrence) and overall average in the period from January 1 to December 31, 2012 in Petrolina-PE. 
virtually rains occurred between March and October, what contributed to increase the thermal discomfort, as will be shown later.

To demonstrate the higher temperatures in the urban environment and show the presence of heat island in relation to its surrounding region, the air temperature differences between the two environments studied are presented in Fig. 3, characterizing the occurrence and intensity of urban heat islands (UHI). Figure 3 indicates the occurrence of UHI nearly every day of the year. The intensity observed generally ranged from low to moderate. However, on 28 April, was recorded $5.3^{\circ} \mathrm{C}$ difference in air temperature between urban and rural areas, featuring occurrence of intensive heat island. Heat island was also characterized in the urban environment in almost every day of the year, although usually with low intensity. However, it highlights that on $29 / 04$ was recorded a difference of $2.6^{\circ} \mathrm{C}$, characterizing a moderate UHI. Also, it is observed the occurrence of heat islands in the urban environment in nearly every day of the year, with a generally weak intensity. It is noteworthy a heating of both the urban and rural areas, a fact that contributes to the reduction of the difference between these two environments. On February 19, 2012 was recorded a difference of $2.3{ }^{\circ} \mathrm{C}$ between the highest maximum temperature in the two environments studied, characterizing island of moderate heat. Gartland (2010) explains that the effect of heat island is more intense on calm and clear days and weaker on cloudy and windy days, since more solar energy is captured on clear days, and milder winds remove the heat in a slower manner, making the heat island becomes more intense. Therefore, it can be concluded that, in any analysis perspective, there is the formation of heat islands in the urban area of Petrolina-PE. Also, it can be said that the minimum relative humidity was very close both in rural as in urban areas. However, in relation to the behavior of the average and maximum air relative humidity, it is observed that the urban environment had, in general, the worst conditions. This fact has the further problem that occurs in the urban area where there is the highest concentration of people and activities in everyday society.

In summary, it can be said that the minimum air relative humidity was very close both in rural as in urban areas (Fig. 4). However, in relation to the behavior of the average and maximum air relative humidity, it is observed that the city environment was presented, in general, less humid. These findings are relevant from a social point of view because the city constitute an area of concentration and movement of most people throughout the year who rely on services as varied as possible, such as trade, health and bank, for example.

If the physical point of view admits the occurrence of such a situation, from a statistical point of view the correlation between the variables studied is presented in Tables 6 and 7. These tables list the annual hourly averages of extremes air temperature and humidity, in urban and rural environments, as well as its value of the correlation coefficient between them. There has been a strong inverse correlation between maximum temperature and minimum humidity $(r=-0.95)$, and between minimum temperature and maximum relative humidity $(r=-0.98)$. This statistical correlation associated with physical reality as possible between such occurrences justify the adaptation of the calculation of thermal discomfort by Thom equation proposed by this work. As observed in the urban area of Petrolina-PE, the data from rural areas indicate also a strong inverse correlation between minimum temperature and maximum hu-

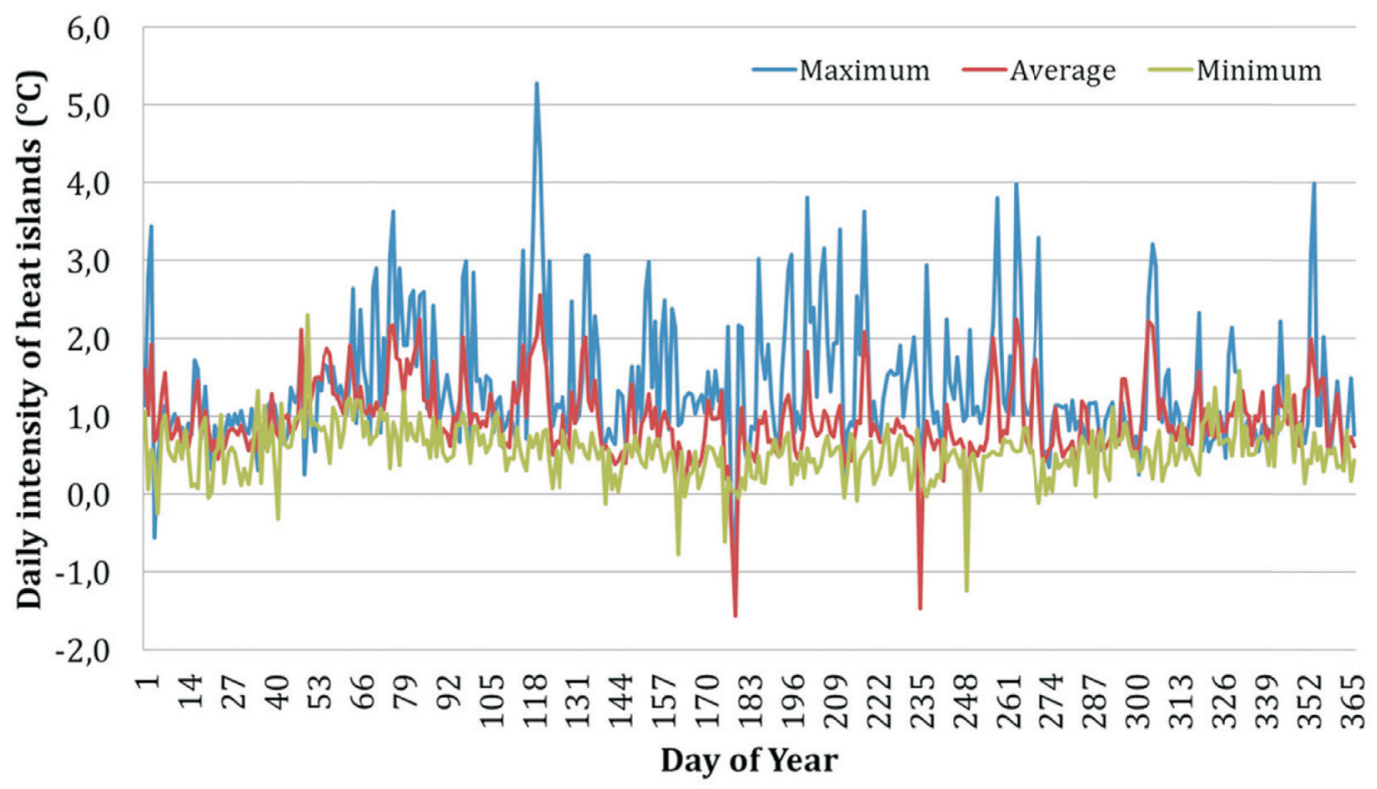

Figure 3 - Occurrence and daily intensity of heat islands in Petrolina-PE in the period from January $1^{\text {st }}$ to December 31, 2012 for minimum, average and maximum air temperature. 
Table 6 - Average annual hourly values and correlation coefficient between maximum temperature $\left(T_{x}\right)$ and minimum relative humidity $\left(R H_{m}\right)$, as well as between the minimum temperature $\left(T_{m}\right)$ and maximum relative humidity $\left(R H_{x}\right)$ in the urban area in the period from January $1^{\text {st }}$ to December 31,2012 in Petrolina-PE.

\begin{tabular}{|c|c|c|c|c|c|c|c|}
\hline \multirow[t]{2}{*}{ Hour } & \multicolumn{2}{|c|}{ Annual average } & \multirow[t]{2}{*}{ Correlation coeficient $(r) T x$ vs. $R H_{m}$} & \multirow[t]{2}{*}{ Hour } & \multicolumn{2}{|c|}{ Annual average } & \multirow{2}{*}{ Correlation coefficient $(r) T_{m} v s . R H_{x}$} \\
\hline & $T_{x}$ & $R H_{m}$ & & & $T_{m}$ & $R H_{x}$ & \\
\hline 0 & 28.3 & 36.4 & & 0 & 22.3 & 79.1 & \\
\hline 1 & 27.4 & 40.5 & & 1 & 21.9 & 79.0 & \\
\hline 2 & 26.7 & 44.4 & & 2 & 21.5 & 80.3 & \\
\hline 3 & 25.7 & 48.0 & & 3 & 21.2 & 80.3 & \\
\hline 4 & 25.1 & 52.3 & & 4 & 20.9 & 81.3 & \\
\hline 5 & 24.8 & 55.3 & & 5 & 20.7 & 82.1 & \\
\hline 6 & 25.3 & 56.5 & & 6 & 20.7 & 82.0 & \\
\hline 7 & 27.1 & 52.8 & & 7 & 21.4 & 79.4 & \\
\hline 8 & 29.2 & 43.4 & & 8 & 22.2 & 76.8 & \\
\hline 9 & 30.8 & 37.3 & & 9 & 23.1 & 73.7 & \\
\hline 10 & 31.9 & 32.5 & & 10 & 24.4 & 68.7 & \\
\hline 11 & 33.3 & 28.0 & & 11 & 25.7 & 62.9 & \\
\hline 12 & 34.4 & 24.1 & & 12 & 26.5 & 59.0 & \\
\hline 13 & 35.3 & 21.4 & -0.95 & 13 & 27.3 & 55.8 & -0.98 \\
\hline 14 & 35.9 & 20.2 & & 14 & 27.7 & 54.4 & \\
\hline 15 & 36.0 & 19.4 & & 15 & 27.8 & 54.1 & \\
\hline 16 & 35.8 & 19.4 & & 16 & 27.0 & 58.4 & \\
\hline 17 & 35.0 & 20.8 & & 17 & 26.2 & 61.8 & \\
\hline 18 & 33.7 & 22.7 & & 18 & 25.0 & 69.5 & \\
\hline 19 & 32.6 & 24.2 & & 19 & 24.5 & 73.7 & \\
\hline 20 & 31.8 & 26.7 & & 20 & 24.1 & 74.8 & \\
\hline 21 & 30.9 & 28.1 & & 21 & 23.6 & 74.7 & \\
\hline 22 & 30.1 & 29.9 & & 22 & 22.9 & 76.5 & \\
\hline 23 & 29.2 & 32.8 & & 23 & 22.5 & 78.5 & \\
\hline 24 & 28.3 & 36.4 & & 24 & 22.3 & 79.1 & \\
\hline
\end{tabular}

Table 7 - Annual hourly average and coefficient of correlation between maximum temperature and minimum air relative humidity, as well as between the minimum temperature and maximum air relative humidity in rural area of Petrolina-PE during the period from January $1^{\text {st }}$ to December $31,2012$.

\begin{tabular}{|c|c|c|c|c|c|c|c|}
\hline \multirow[t]{2}{*}{ Hour } & \multicolumn{2}{|c|}{ Annual average } & \multirow[t]{2}{*}{ Correlation coefficient $(r) T x v s . R H_{m}$} & \multirow[t]{2}{*}{ Hour } & \multicolumn{2}{|c|}{ Annual average } & \multirow[t]{2}{*}{ Correlation coefficient (r) $T_{m} v s . R H_{x}$} \\
\hline & $T_{x}$ & $R H_{m}$ & & & $T_{m}$ & $R H_{x}$ & \\
\hline 0 & 24.5 & 57.3 & & 0 & 23.5 & 62.5 & \\
\hline 1 & 23.8 & 61.1 & & 1 & 22.9 & 65.8 & \\
\hline 2 & 23.1 & 64.6 & & 2 & 22.3 & 68.6 & \\
\hline 3 & 22.6 & 67.6 & & 3 & 21.8 & 71.2 & \\
\hline 4 & 22.1 & 70.2 & & 4 & 21.4 & 73.6 & \\
\hline 5 & 21.7 & 72.1 & & 5 & 21.1 & 75.2 & \\
\hline 6 & 22.8 & 68.8 & & 6 & 21.4 & 74.5 & \\
\hline 7 & 24.2 & 62.7 & & 7 & 22.7 & 69.8 & \\
\hline 8 & 25.8 & 55.7 & & 8 & 23.9 & 64.7 & \\
\hline 9 & 27.4 & 48.9 & & 9 & 25.4 & 58.4 & \\
\hline 10 & 28.9 & 42.7 & & 10 & 26.9 & 51.9 & \\
\hline 11 & 30.2 & 37.6 & & 11 & 28.2 & 45.9 & \\
\hline
\end{tabular}


Table 7 - (cont.)

\begin{tabular}{|c|c|c|c|c|c|c|c|}
\hline \multirow[t]{2}{*}{ Hour } & \multicolumn{2}{|c|}{ Annual average } & \multirow[t]{2}{*}{ Correlation coefficient $(r) T x$ vs. $R H_{m}$} & \multirow[t]{2}{*}{ Hour } & \multicolumn{2}{|c|}{ Annual average } & \multirow[t]{2}{*}{ Correlation coefficient (r) $T_{m} v s . R H_{x}$} \\
\hline & $T_{x}$ & $R H_{m}$ & & & $T_{m}$ & $R H_{x}$ & \\
\hline 12 & 31.3 & 33.9 & & 12 & 29.4 & 41.0 & \\
\hline 13 & 32.1 & 31.2 & -0.99 & 13 & 30.5 & 37.1 & -0.99 \\
\hline 14 & 32.5 & 29.6 & & 14 & 31.2 & 34.2 & \\
\hline 15 & 32.7 & 28.9 & & 15 & 31.6 & 32.7 & \\
\hline 16 & 32.4 & 29.3 & & 16 & 31.3 & 32.5 & \\
\hline 17 & 31.5 & 31.3 & & 17 & 29.7 & 35.8 & \\
\hline 18 & 29.8 & 35.4 & & 18 & 28.0 & 41.2 & \\
\hline 19 & 28.2 & 40.3 & & 19 & 27.0 & 45.3 & \\
\hline 20 & 27.4 & 43.4 & & 20 & 26.3 & 48.4 & \\
\hline 21 & 26.7 & 46.2 & & 21 & 25.7 & 51.2 & \\
\hline 22 & 26.0 & 49.4 & & 22 & 24.9 & 54.9 & \\
\hline 23 & 25.3 & 53.0 & & 23 & 24.2 & 58.9 & \\
\hline 24 & 24.5 & 57.3 & & 24 & 23.5 & 62.5 & \\
\hline
\end{tabular}

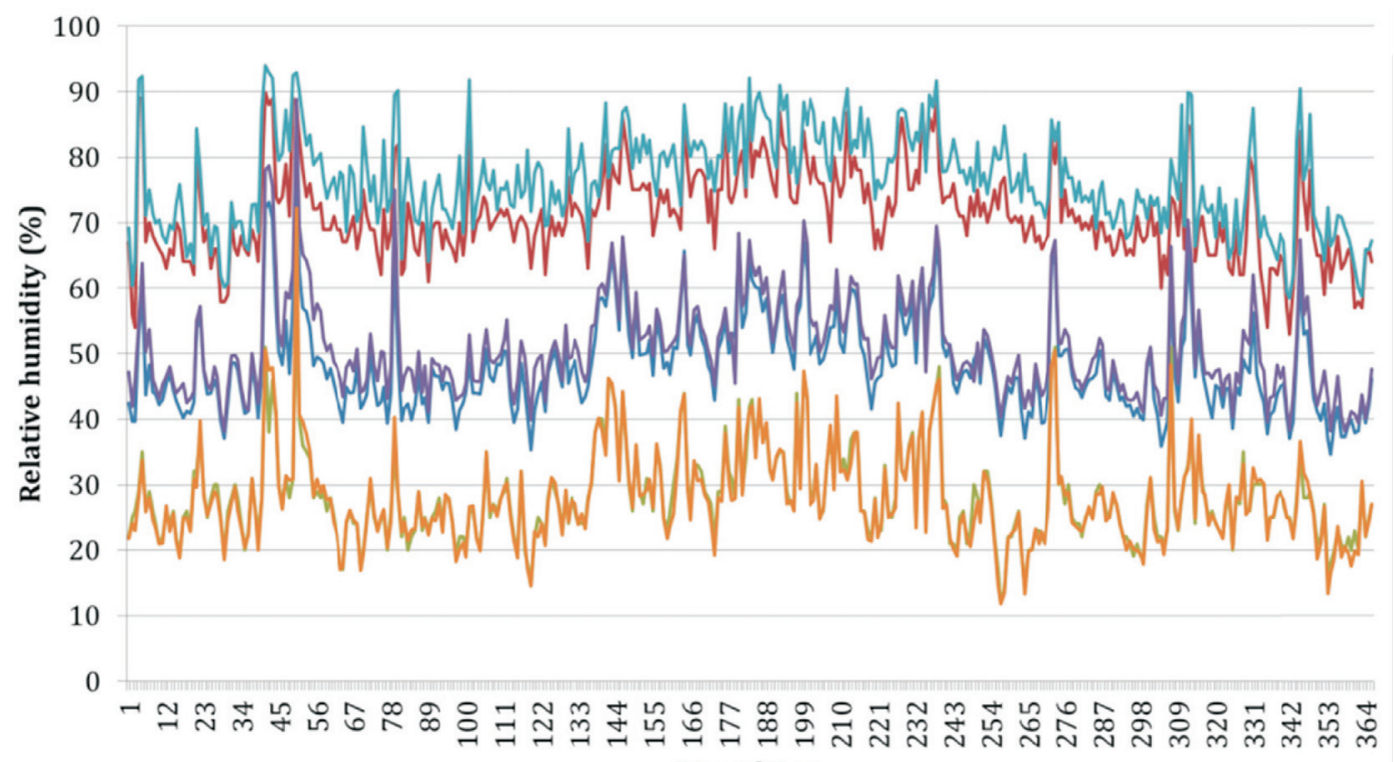

Day of Year

$$
\text { -Avg_Urban - Max_Urban - Min_Urban - Avg_Rural - Max_Rural - Min_Rural }
$$

Figure 4 - Air relative humidity in rural and urban areas of Petrolina-PE in the period from January $1^{\text {st }}$ to December 31, 2012 for: (A) minimum; (B) average and $(\mathrm{C})$ maximum.

midity $(r=-0.99)$, as well as between maximum temperature and minimum relative humidity $(r=-0.99)$ (Table 7).

Once proven the physical and statistically correlation between temperature and relative humidity, the thermal discomfort index was calculated based on the maximum temperature and minimum relative humidity and based on minimum temperature and maximum relative humidity. For the urban area, a partial thermal comfort in the period between the end of April and beginning of October was obtained (Fig. 5). However, in the periods January to March and November to December, the situation was characterized as thermal discomfort. It was also observed that the vast majority of days studied showed partial comfort condition. That is, even considering the thermal discomfort index based on the minimum values of air temperature, thermal comfort period is limited from late June to early October. Therefore, based on the results obtained for $D I T_{m}$, representative of the situation early in the morning, yet $23.0 \%$ of the days were comfortable, $77.0 \%$ of days had partial comfort and no day showed thermal discomfort. In contrast, during 


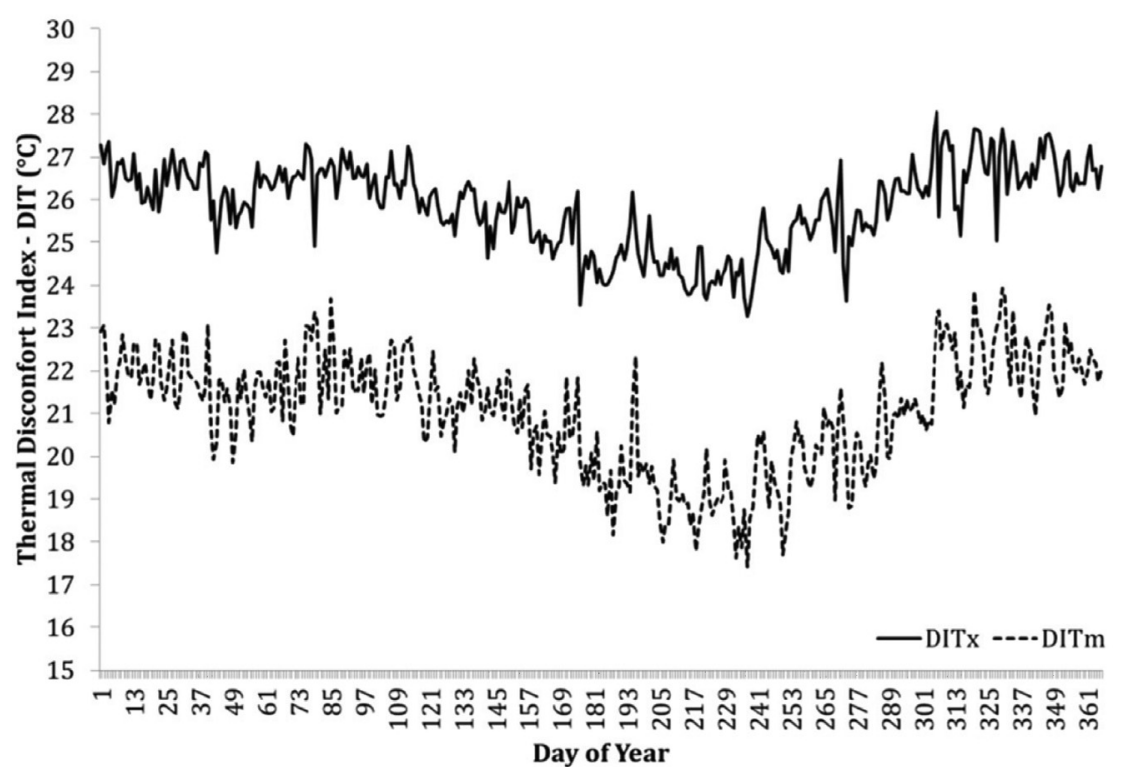

Figure 5 - Maximum $\left(D I T_{x}\right)$ and minimum $\left(D I T_{m}\right)$ thermal discomfort index in the urban area of Petrolina-PE during the period from January $1^{\text {st }}$ to December 31, 2012.

the morning hours, represented by $71.6 \%$ of days surveyed had partial comfort and $28.4 \%$ of the days were thermally uncomfortable.

Looking at Fig. 6, we see that the $D I T_{x}$ in the rural area showed partial thermal comfort in most days from January to October. However, from mid-October until December the situation was thermal discomfort. Also, the annual march of the $D I T_{m}$ had partial comfort on most days studied. That is, even considering the thermal discomfort index based on the minimum values of air temperature, thermal comfort period is limited from June to mid-October.
Therefore, the results obtained for the thermal disconfort index $D I T_{m}$ indicated that the morning shift $41.5 \%$ of the days were comfortable, while $58.5 \%$ of the days were partial comfort. However, in the afternoon, represented by $D I T_{x} 87.7 \%$ of days surveyed had partial comfort and $12.3 \%$ of the days were thermally uncomfortable situations and were not recorded.

Therefore, the comparison between urban environments and their rural surrounding region, shows that the urban area of the city of Petrolina presents changes in their climatic variables (temperature, relative humidity and wind

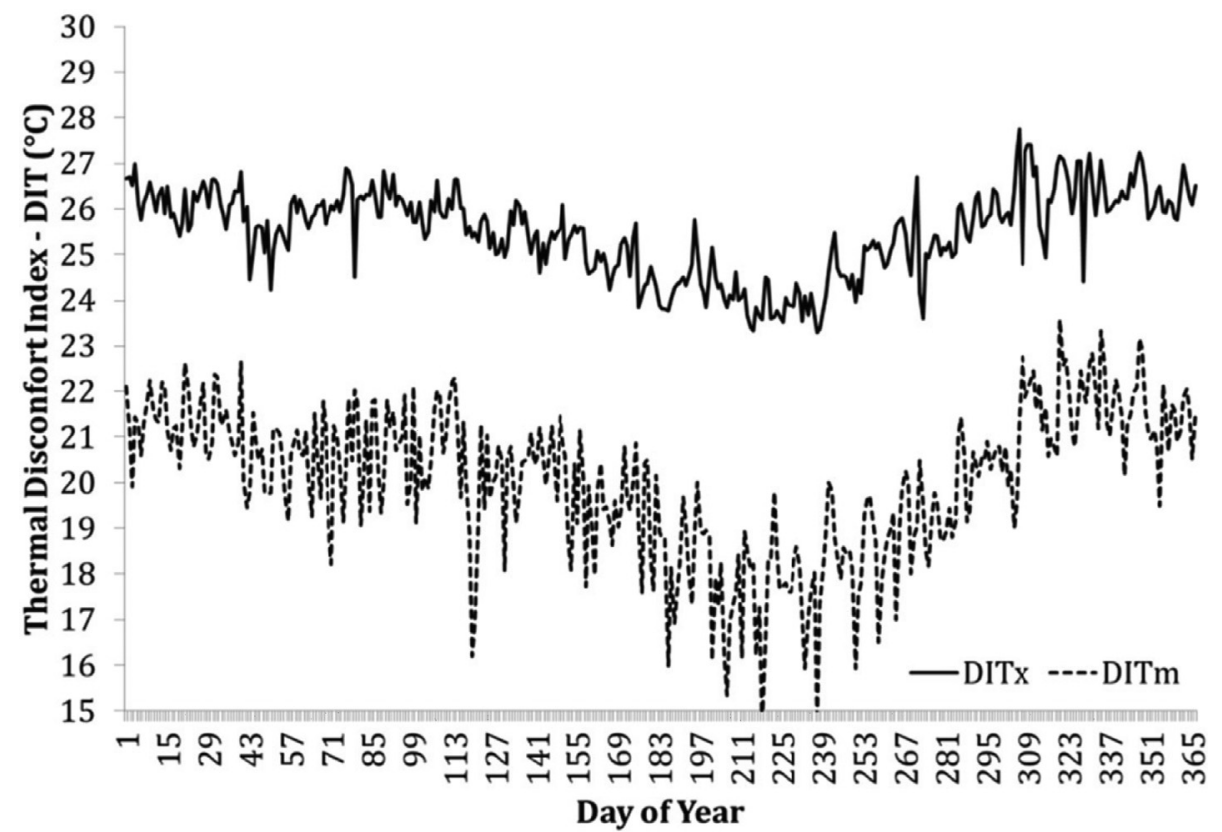

Figure 6 - Maximum $\left(D I T_{x}\right)$ and minimum $\left(D I T_{m}\right)$ thermal discomfort index in rural Petrolina-PE during the period from 01/01 to 31/12/2012. 
speed), especially during the evening period, impacting directly in the thermal generating discomfort for the population.

\section{Conclusions}

The evaluation of the thermal conditions of Petrolina municipality during the period from January $1^{\text {st }}$ to December 31,2012, using data from automatic weather stations installed in urban and rural areas, allowed to make the following conclusions:

1) Heat islands with varying intensity are characterized in the urban area of the municipality;

2) The naturally adverse weather conditions in the Semiarid region, potentiated by constructive elements of urban space, contribute to the expansion of heat islands and thermal discomfort of their people;

3) Applying the adaptation of Thom equation for obtaining the thermal discomfort index to Petrolina-PE, it was observed that the urban area records thermal comfort always lower than that observed in the rural area;

4) Therefore, it can be said that the climate of the Petrolina municipality is influenced by the design characteristics of urban areas. This association contributes to the formation of heat islands and thermal discomfort, afforestation is an effective mechanism to mitigate the adverse effects of this condition and improve the quality of life of the population.

\section{Acknowledgments}

The authors are grateful to the CNPq for funding the Research Project $n^{\circ}$ 446172/2015-4, the Research Productivity Grant for the fourth author, as well as the CAPES for funding the Research Project n ${ }^{\circ} 88887.091737 / 2014-01$.

\section{References}

ALEXANDRIA, E.; JONESB, P. Temperature decreases in an urban canyon due to green walls and green roofs in diverse climates. Building and Environment, v. 43, p. 480-493, 2008.

AMORIM, M.C.C.T. Ilhas de calor em Birigui/SP. Revista Brasileira de Climatologia, v. 1, p. 121-130, 2005.

AMORIM, M.C.C.T.; DUBREUIL, V.; QUENOL, H.; SANT'ANA NETO, J.L. Características das ilhas de calor em cidades de porte médio: exemplos de Presidente Prudente (Brasil) e Rennes (França). Confins [Online], 7/2009, posto online em 31 outubro 2009. URL: http://confins.revues.org.

ANDRADE, H.O. Clima urbano - natureza, escalas de análise e aplicabilidade. Revista Portuguesa de Geografia, v. 80, p. 66-91, 2005.

ARAÚJO, R.R.; SANTANNA NETO, J.L. O processo de urbanização na produção do clima urbano de São Luiz-MA. In: SANTANNA NETO, J.L. O clima das cidades brasileiras. João Lima Santanna Neto (org). - Presidente Prudente: [s/n], 2002.

AZEVEDO, T.R.; TARIFA, J.R. O ritmo semanal das atividades humanas e o clima a região metropolitana de São
Paulo. Laboratório de Climatologia e Biogeografia. Departamento de Geografia, Faculdade de Filosofia, Letras e Ciências Humanas, Universidade de São Paulo, Série TA Texto 008, 2001.

BEZERRA, P.T.C. A Influência da urbanização no clima das cidades de Petrolina/PE e Juazeiro/BA. Dissertação de Mestrado em Recursos Naturais da Universidade Federal de Campina Grande - PB. Fevereiro, 2009.

COLTRI, P.P.; VELASCO, G.D.N.; POLIZEL, J.L.; DEMETRIO, V.A.; FERREIRA, N.J. Ilhas de calor da estação de inverno da área urbana do município de Piracicaba/SP. XIII Simpósio de Sensoriamento Remoto, Florianópolis/SC... Anais. INPE, p. 5151-5157. Abril, 2007.

GOMÉZ, F.; TAMARIT, N.; JABALOYES, J. Green zones, bioclimatics studies and human comfort in the future development of urban planning. Landscape and Urban Planning, v. 55, p. 151-161, 2001.

GRIMMOND, S. Urbanization and global environmental change: local effects of urban warming. The Royal Geographical Society, v.173, p. 83-88, 2007.

IBGE - Instituto Brasileiro de Geografia e Estatística. Censo demográfico do Brasil. Rio de Janeiro, 2010.

KALNAY, E.; CAI, M. Impact of urbanization and land-use change on climate. Nature, v.432, p.528-531, 2003.

LAMBERTS, R.; XAVIER, A.A.P. Conforto térmico e stress térmico. Universidade Federal de Santa Catarina. Centro tecnológico. Departamento de Engenharia Civil. Florianópolis, 2002.

LAMBERTS, R.; XAVIER, A.A.P; GOULART, S.; VECCHI, R. de. Conforto e stress térmico. Universidade Federal de Santa Catarina. Centro tecnológico. Departamento de Engenharia Civil. Florianópolis, 2011.

MONTEIRO, C.A.F.; MENDONÇA, F. (Org.). Clima urbano. São Paulo: Contexto, 2003.

MONTEIRO, C.A.F. Teoria e clima urbano. São Paulo: IGEOG/USP, 181p. Série Teses e Monografias, 25, 1976.

MONTEIRO, L.M.; ALUCCI, M.P. Índices de conforto térmico em espaços abertos. Parte 1. VIII Encontro Nacional e VI Encontro Latinoamericano de conforto no ambiente construído. São Paulo. Anais...Maceió, ANTAC, 2005.

OKE, T.R. Canyon geometry and the nocturnal urban heat island: Comparision of scale model and field observations. Journal of Climatology, v. 1, p. 237-254, 1991.

OKE, T.R.; JOHNSON, G.T.; STEYN, D.G.; WATSON, I.D. Simulation of surface urban heat islands under "Ideal" Conditions at night Part 2: Diagnosis of causation. Boundary-Layer Meteorology, v.56, p.339-358, 1996.

OKE, T.R; ZEUNER, G.; JÁUREGUI, E. The Surface Energy Balance in Mexico City. Atmospheric Environment, v. 26B, p. 433-444, 1992.

PEREZ, J.C; SÁNCHEZ, M.A.V.; BARRADAS, V.L. Clima, urbanización y uso del suelo enciudades tropicales de Mexico. Red Nacional de Investigación Urbana, Puebla, México, Ciudades 51, jun-set. 2001.

SILVA, V.P.R;. AZEVEDO, P.V.; BRITO, R.S.; CAMPOS; J.H.B.C. Evaluating the urban climate of a typically tropical city of northeastern Brazil. Environmental Monitoring of Assessment. v.161, p.45-59, 2010.

This is an Open Access article distributed under the terms of the Creative Commons Attribution Non-Commercial License which permits unrestricted non-commercial use, distribution, and reproduction in any medium provided the original work is properly cited. 